(normal and reduced with supplementary lysine). A differential scale of feeding was applied according to sex : liberal in females, restricted in castrates during the finishing period (-3 p. 100 during the whole experiment).

The levels of lysine and total balanced protein (after lysine supplementation) supplied to the animals were those recommended by I.N.R.A. (1984), i.e., 2.5 and $2.2 \mathrm{~g}$ lysine/Mcal DE, 45 and $40 \mathrm{~g}$ protein / Mcal DE within the live weight intervals $27-52$ and $52-100 \mathrm{~kg}$, respectively. The overall results between 27 and $100 \mathrm{~kg}$ live weight for average daily gain (ADG) and feed conversion ratio (FCR) were the same in treatments supplemented with lysine as in controls, both with maize or wheat : ADG (g) 701 vs 699 with maize, 711 vs 690 with wheat; FCR, 3.13 vs 3.14 with maize, 3.25 vs 3.32 with wheat.

Sex $\times$ treatment interactions were noted for carcass characteristics. In females, carcass fatness increased with lysine supplemented diets, but only with wheat : loin/backfat ratio was 1.97 vs 2.38 while no difference was observed with maize $(2.07$ vs 2.11$)$. This increase in fat deposition is explained by the improvement in dietary protein utilization, following lysine supplementation and reduction in protein level, but also probably by an inadequate supply of the second limiting amino acid, i.e., threonine, in wheat-soyabean meal diet at a reduced level of protein $(0.42$ p. 100 during the finishing period). On the opposite, in castrated males, the improvement in amino acid balance in combination with a reduced protein level, in the case of limiting supply of dietary energy, exerted a favourable effect on lean tissue deposition : loin/backfat ratio was 2.20 vs 2.94 for the mean of the two cereals.

When cereal diets are supplemented with industrial lysine, the amount of spared protein is about 50 p. 100 higher with wheat containing $11 \mathrm{p} .100$ protein than with maize, in combination with soyabean meal. With wheat, as much as $17 \mathrm{~kg}$ soyabean meal (48.5 p. 100 protein) and $5 \mathrm{~kg}$ protein per pig can be saved within the live weight range $27-100 \mathrm{~kg}$. This corresponds to a reduced level of incorporation of almost 5 points of soyabean meal and a little more than 2 points of protein in the diet.

\title{
Comparative utilization of maize, wheat and barley by the bacon pig Survey of 22 trials made by I.T.C.F.-A.G.P.M.-S.E.A.P.
}

\author{
F. GROSJEAN *, M. SEROUX *, J. CASTAING** \\ * I.T.C.F., 8, avenue du Président-Wilson, 75116 Paris \\ ** A.G.P.M., 22, boulevard Tourasse, 64000 Pau
}

Twenty two trials were conducted in bacon pigs to compare monocereal diets including soyabean meal and mineral and vitamin mixture. Six trials were made in ad libitum feeding conditions, 3 in ad libitum feeding conditions during the growing period followed by a plateau during the finishing period and 13 in restricted conditions. A total of 55 batches of cereals (maize, wheat, two-row barley, six-row barley) were compared in 2140 pigs of both sexes between 25 and $103 \mathrm{~kg}$ live weight. In each trial diets were formulated so as to exhibit the same lysine/DE ratio.

In ad libitum conditions, feed intakes was lower with high energy diets. Energy intake was similar for maize-based and wheat-based diets; it was lower for barley-based diets. The animal growth and carcass fatness were similar with maize and wheat diets. They were lower with barley-based diets. used.

In restricted conditions, growth and carcass fatness were not affected by the cereal

In all the cases, feed conversion ratio decreased with the energy concentration in the diet (about 0.1 point per $100 \mathrm{kcal} \mathrm{DE}$ ). By contrast, energy conversion ratio was not affected by the nature of the cereal.

These trials showed that the energy system based on digestible energy and energy value of provisional raw materials used seems satisfactory for simple feeds. 
Carcass yield decreased with the energy concentration of the diet $(0.30$ point per $100 \mathrm{kcal} \mathrm{DE})$.

The gastrooesophageal mucosa was less affected by the low energy diets (barley) than by the other diets (maize and wheat). Nevertheless, maize appeared slightly more ulcerogenous than wheat.

\title{
General survey of the energy and protein value of French triticale
}

\author{
J.M. PEREZ, D. BOURDON
}

I.N.R.A., Station de Recherches Porcines, Saint-Gilles, 35590 L'Hermitage

Five digestibility experiments have been made since 1977 with the aim of determining the nutritive value of different triticale varieties for the pig, especially the Clercal variety selected by the I.N.R.A. A total of 32 Large White castrated male pigs were used distributed into eight groups of four pigs per diet and kept in individual pens specially equipped for digestive balance. After an adaptation period, excreta (faeces and urine) were collected for 10 consecutive days. The experimental diets only based on triticale (97 p. 100) were supplemented with minerals and vitamins. Eight triticale samples were tested.

According to the results obtained, the mean energy value (DE) of triticale for the pig was estimated at $3725( \pm 20) \mathrm{kcal} / \mathrm{kg} \mathrm{DM}$, i.e., half between that of rye $(3660 \mathrm{kcal})$ and wheat $(3830 \mathrm{kcal})$. The apparent digestibility of triticale proteins $(80.7 \mathrm{p} .100)$ was also half between the values obtained with these two cereals.

\section{Importance of cereal phytase activity for phytate phosphorus Utilization by growing pigs fed triticale or maize diets}

\author{
Annie FOURDIN, Nicole FONTAINE, A. POINTILLART \\ I.N.R.A., Station de Recherches de Nutrition, 78350 Jouy-en-Josas
}

In contrast to maize, triticale exhibits a high phytase activity. This dietary enzyme enhances phytic phosphorus digestibility as demonstrated in wheat fed pigs. To study phosphorus utilization, 12 growing pigs were fed either a maize (M) or a triticale (T) based diet for 6 weeks. Both diets exhibited the same energy, protein, vitamin D (1 $500 \mathrm{IU} / \mathrm{kg}$ diet $)$, calcium (0.5 p. 100$)$ and phosphorus $(0.4$ p. 100) content. No inorganic P was added to either diets. A 10-day balance study was carried out to estimate $\mathrm{Ca}$ and $\mathrm{P}$ absorption and retention.

Both diets caused a phosphorus deficiency, but hypophosphatemia occurred more rapidly while hypercalciura and hypophosphaturia were more marked with maize than with triticale. $\mathbf{P}$ absorption and retention were higher with $\mathrm{T}$ diet than with $\mathrm{M}$ diet : apparent absorption, $65 \pm 1$ vs $48 \pm 3$ p. 100 intake, respectively $(\mathbf{P}<0.01)$. This was probably related to the high phytase activity of triticale since phosphatase activities (phytase and alkaline phosphatase) of intestinal mucosa were similar in both groups of animals. Calcium absorption was not modified by the kind of cereal given, whereas Ca retention was greater on triticale than on maize diet. The higher mineral retention observed in triticale fed pigs led to significantly higher bone mineral contents. In addition, average daily gain and feed efficiency were significantly better in the triticale fed group. In conclusion, the higher the dietary phytase activity, the higher the phytate phosphorus availability. 